\title{
Companheiras em greve : o movimento paredista da União das Costureiras em junho de 1919
}

\author{
Beatriz Luedemann Campos \\ Bacharel em História pela Universidade Federal de \\ São Paulo (Unifesp)
}

\section{Resumo}

O artigo reconstrói a história da Greve de Junho de 1919 realizada por mulheres operárias (costureiras, bordadeiras e chapeleiras) que trabalhavam em ateliês de moda e oficinas de costura no Rio de Janeiro. Organizadas no sindicato União das Costureiras e Classes Anexas, elas lutaram por melhores condições de trabalho, aumento salarial, jornada de oito horas, entre outras pautas próprias da categoria. A metodologia de pesquisa envolveu o uso de fontes históricas de grande imprensa, imprensa operária, entrevistas e história oral.

Palavras-chave História Social do Trabalho - Movimento operário na Primeira República brasileira - Greves - Sindicatos - História das Mulheres.

\section{Submissão}

$$
\text { I5/O8/202I }
$$

Aprovação

Publicação

$30 / 12 / 2021$ 


\title{
Women comrades on strike: the strike movement of the Seamstress' Union in June 1919
}

\begin{abstract}
The essay aims to reconstruct the history of the June Strike of 1919, organized by women workers (seamstresses, embroiderers and hatters) who worked in fashion ateliers and sewing workshops in Rio de Janeiro. Organized in the Seamstress' Union, they fought for better working conditions, pay raise, eight-hour working day, among other class demands. The methodology of the research uses historical sources from the mainstream press, labor press, interviews and oral history.
\end{abstract}

Keywords Social History of Work - Workers Movement in First Brazilian Republic - Strikes Unions - Women's History.

\section{Mujeres compañeras en huelga: el movimiento de huelga del Sindicato de Costureras en junio de 1919}

\section{Resumen}

El artículo reconstruye la historia de la Huelga de Junio de 1919, organizada por las trabajadoras (costureras, bordadoras y sombrereras) que trabajaban en los talleres de moda y costura de Río de Janeiro. Organizadas en el Sindicato de Costureras, lucharon por mejores condiciones de trabajo, aumento salarial, jornada de ocho horas de trabajo, entre otras reivindicaciones de clase. La metodología de la investigación utiliza fuentes históricas de la prensa convencional, prensa obrera, entrevistas e historia oral.

Palabras clave Historia Social del Trabajo - Movimiento obrero en la Primera República brasileña - Huelgas - Sindicatos - Historia de las Mujeres. 


\section{Introdução}

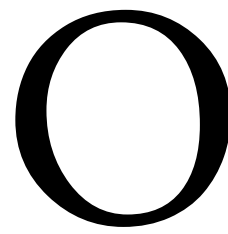

movimento operário na Primeira República é marcado pela diversidade de associações de trabalhadores que nelas se auto-organizavam. Para Claudio Batalha, ${ }^{ }$a definição de operário inclui todos os trabalhadores manuais urbanos. As suas precárias condições de vida levaram sua organização para a resistência, defesa e luta pela conquista de seus direitos. Assim, eles organizaram greves e construíram sindicatos. Segundo Glaucia Fraccaro, ${ }^{2}$ as mulheres operárias nunca estiveram ausentes destes movimentos, e, ainda que fossem pouco sindicalizadas, encontravam diversas formas de sociabilidade e luta.

Nas últimas décadas, a historiografia do movimento operário brasileiro da Primeira República tem tratado da especificidade das condições e das lutas das mulheres trabalhadoras no período. Sobre os movimentos grevistas, é possível citar exemplos de algumas pesquisas de âmbito regional sobre a greve das cigarreiras na fábrica de tabaco Lafayette, em Recife, em 1903,3 ou as greves de mulheres em Pelotas (RS) e Rio Grande (RS). ${ }^{4}$ Sobre a história das mulheres dos anos 1980, destacam-se a historiadora Margareth Rago,s que tratou sobre a resistência feminina anarquista, e a socióloga Elisabeth Lobo. ${ }^{6}$ Luigi Biondi, Edilene Toledo ${ }^{7}$ e Fraccaro destacaram a ampla participação feminina na Greve Geral de 1917, em São Paulo, e no interior das ligas operárias dos bairros. ${ }^{8}$

A União das Costureiras e Classes Anexas (1919-1922) foi um sindicato feminino de orientação sindicalista revolucionária, integrante da Federação dos Trabalhadores do Rio de Janeiro. Em junho de 1919, as costureiras, chapeleiras e bordadeiras da União

I BATALHA, C. O movimento operário na Primeira República. Rio de Janeiro: Zahar, 2000.

2 FRACCARO, G. Os direitos das mulberes: feminismo e trabalbo no Brasil (I9I7-I937). Rio de Janeiro: Editora FGV, 2018.

3 SOUZA, F. A. "As cigarreiras revoltosas e o movimento operário: história da primeira greve feminina do Recife e as representações das mulheres operárias na imprensa”. Cadernos Pagu, n. 55, 2019.

4 SILVA, M. A. G. Rompendo o silêncio: mulberes operárias em Pelotas e Rio Grande (I89o- Ig2o). Dissertação (Mestrado) - Pontifícia Universidade Católica do Rio Grande do Sul, Porto Alegre, I998.

5 RAGO, M. Do cabaré ao lar: a utopia da cidade disciplinar: Brasil (I89o-1930). Rio de Janeiro: Paz e Terra, 1985 .

6 SOUZA-LOBO, E. A classe operária tem dois sexos: trabalbo, dominação e resistência. 3. ed. São Paulo: Expressão Popular, 202I.

7 BIONDI, L.; TOLEDO, E. Uma revolta urbana: a Greve Geral de IgI7 em São Paulo. São Paulo: Fundação Perseu Abramo, 2018.

8 FRACCARO, G. "Mulheres, sindicato e organização política nas greves de i9I7 em São Paulo". Revista Brasileira de História, v. 37, n. 76, p. 73-90, 2009. 


\section{REVISTA ANGELUS NOVUS}

organizaram uma greve por melhores condições de trabalho em ateliês, casas de moda e oficinas de costura, que foi noticiada por jornais da grande imprensa em suas colunas operárias e policiais. Os periódicos que faziam oposição aos governos oligárquicos da Primeira República apoiavam suas reivindicações, assim como as pautas operárias em geral, com o objetivo de conquistar apoio popular aos seus interesses políticos. ${ }^{9}$

Além dos jornais, as fontes de história oral foram essenciais para a reconstrução da história desta greve; por exemplo, os depoimentos de Elvira Boni - costureira, militante anarquista e filha de imigrantes italianos, líder sindical da União das Costureiras - para a historiadora Ângela de Castro Gomes, ${ }^{10}$ em 1983, e as entrevistas realizadas, em 2020, com sua filha, Zeni Lacerda Pamplona, e suas netas, Consuelo e Eneida. ${ }^{\text {II }}$

É importante ressaltar que o movimento de paralisação do trabalho não foi um modelo importado da Europa, mas uma prática de luta historicamente realizada pelos brasileiros, ${ }^{12}$ por exemplo, a greve dos trabalhadores escravizados na Bahia, em I857..$^{13}$ Por este motivo, além da palavra francesa gréve, utilizo o termo movimento paredista ou paredes, tal como eram conhecidos. Essas também eram as expressões que apareceiam nos jornais que divulgavam o movimento da União das Costureiras.

\section{Cotidiano de trabalho e formação da União das Costureiras}

A União das Costureiras foi fundada em i8 de maio de 1919, duas semanas após uma grande manifestação em Io de Maio, na praça Mauá;:14 portanto, em um momento de forte agitação política dos trabalhadores. ${ }^{15}$ Naquele momento, o movimento operário internacional era influenciado pela Revolução Russa de 1917. ${ }^{16} \mathrm{~A}$ organização sindicalista revolucionária, que privilegiava a união de toda a classe trabalhadora, independentemente da orientação política, ${ }^{17}$ incorporou operárias de diversas correntes

SODRÉ, N. W. História da imprensa no Brasil. 2. ed. Rio de Janeiro: Graal, 1977.

GOMES, A. C. Velhos militantes: depoimentos. Rio de Janeiro: Zahar, 1988.

CAMPOS, B. L. "Avante, companheiras!": as lutas sindicais das operárias do Rio de Janeiro na União das Costureiras a partir da trajetória de Elvira Boni. Monografia (Graduação) - Universidade Federal de São Paulo, São Paulo, 202I.

GOMES, F.; NEGRO, A. L. "As greves antes da grève: as paralisaçôes do trabalho feitas por escravos no século XIX". Ciência e Cultura, v. 65, p. 56-59, 2013.

I3 REIS, J. J. Ganhadores: a Greve Negra de 1857 na Babia. São Paulo: Companhia das Letras, 2019.

I4 LACERDA, E. B. "Elvira Boni: anarquismo em família”. GOMES, A. C. Velhos militantes: depoimentos. Rio de Janeiro: Zahar, I988.

Is BATALHA, C. O movimento operário na Primeira República. Rio de Janeiro: Zahar, 2000.

I6 MONIZ BANDEIRA, L. A. O ano vermelho: a Revolução Russa e seus reflexos no Brasil. São Paulo: Expressão Popular, 2004.

$4 \cdot$ ano XII, n. 17, 202I • ISSN 2179-5487 
ideológicas, entre elas, a anarquista Elvira Boni e as comunistas Elisa Gonçalves de Oliveira e Emma Silveira.

Aderiram ao sindicato cerca de duzentas operárias que trabalhavam como costureiras, chapeleiras, bordadeiras, ajudantes e aprendizes em 39 fábricas, oficinas, ateliês e casas de moda do Rio de Janeiro. ${ }^{18}$ As proprietárias desses estabelecimentos - suas patroas -, majoritariamente imigrantes de origem francesa, eram chamadas por elas de "madames". Desde meados do século XIX, esses ateliês de moda surgiram no processo de industrialização e substituição da agulha pela máquina de costura na confecção de roupas. Durante o Império, as oficinas empregavam mão de obra feminina e escravizada, e, após a Abolição da Escravatura, em I888, as costureiras dos ateliês passaram a receber salários. A justificativa para contratar apenas mulheres era uma suposta "vocação natural” feminina em relação ao cuidado com as roupas. Assim, tal como o ofício de lavadeira, por exemplo, a profissão de costureira era visto como uma extensão do trabalho doméstico, que se modernizava e se industrializava. ${ }^{19}$

O cotidiano de trabalho das costureiras no período da Primeira República era difícil. A jornada de trabalho era, em média, de dez horas, sem tempo para lazer ou descanso. ${ }^{20}$ Os salários, que já eram baixos, não acompanharam o aumento dos preços dos bens de primeira necessidade, que subiam desde o fim da Primeira Guerra, em I9I8. Elas confeccionavam diversas peças de roupas, principalmente femininas, como vestidos caros, e, assim, sustentavam a vida de luxo das "madames" e senhoras - tanto das patroas quanto das clientes - que viviam e passeavam no centro do Rio de Janeiro. ${ }^{21}$

Havia também problemas com a alimentação no local de trabalho. De acordo com as entrevistas com Elvira Boni e com sua filha e netas, assim como os relatos encontrados nos periódicos, muitas delas recebiam apenas um copo de leite, um pão de milho ${ }^{22}$ ou um alimento de baixa qualidade no almoço. ${ }^{23}$ Por sua vez, aquelas que levavam marmita, tinham que comer no banheiro para não sujar o ateliê de costura. ${ }^{24}$ As condições higiênicas das oficinas eram denunciadas como precárias, especialmente

I7 TOLEDO, E. Anarquismo e sindicalismo revolucionário: trabalhadores e militantes na Primeira República. São Paulo: Fundação Perseu Abramo, 2004.

I8 "As costureiras organizam-se. Uma grande assembleia na União dos Alfaiates. Foi criada a sua associação de classe”. A Razão, Rio de Janeiro, I9 maio 1919, p. 4.

I9 MONTELEONE, J. M. "Costureiras, mucamas, lavadeiras e vendedoras: o trabalho feminino no século XIX e o cuidado com as roupas (Rio de Janeiro, I850-1920)”. Revista Estudos Feministas, v. 27, n. I, 2019.

20 “União das Costureiras”. A Razão, Rio de Janeiro, I6 jun. 19I9. Movimento operário: manifestos, p. 6.

2I LACERDA, E. B. "Elvira Boni: anarquismo em família”. GOMES, A. C. Velhos militantes: depoimentos. Rio de Janeiro: Zahar, 1988.

22 "Vencerão! Devem vencer...! A greve das costureiras desperta entusiasmo em todas as classes. Aspecto do movimento. Uma violência deprimente. A União das Costureiras”. A Razão, Rio de Janeiro, I8 jun. I9I9, p. I.

23 LACERDA, op. cit. 


\section{REVISTA ANGELUS NOVUS}

nas clandestinas. ${ }^{25}$ As costureiras da União, em seus manifestos, relacionavam questões de saúde e doença ao trabalho, como a tuberculose, ${ }^{26}$ e o cansaço físico, especialmente com as horas extras. ${ }^{27}$ Elvira Boni conta que, durante a epidemia de gripe espanhola, em I9I8, contraiu o vírus, e, mesmo com febre, foi trabalhar. ${ }^{28}$

Ainda mais difícil era a situação das meninas aprendizes. Elvira, por exemplo, começou a trabalhar como aprendiz aos doze anos, ${ }^{29}$ e o salário, que variava entre I5\$ooo e $30 \$$ ooo por mês, segundo ela e muitas outras relatavam, não era suficiente nem para pagar a passagem do bonde. ${ }^{30}$ Elvira lembra que passou os primeiros três meses de trabalho sem receber salário. Elas faziam todo tipo de trabalho: “O primeiro trabalho de aprendiz era catar alfinetes do chão, passar a vassoura na sala, chulear, arrematar as costuras." ${ }_{31}$

O trabalho era dividido por uma hierarquia. As "perfeitas", como eram chamadas as saieiras e corpinheiras, ${ }^{32}$ recebiam os maiores salários, de $120 \$ 000$ a $200 \$ 000$ mensais. As ajudantes ganhavam de $45 \$ 000$ a $85 \$ 000$. E, por último, as aprendizes, que passavam por muitas dificuldades para se qualificarem e se tornar uma costureira "perfeita". ${ }^{33}$ As chapeleiras normalmente trabalhavam em outras oficinas, específicas para a confecção de chapéus. ${ }^{34}$

No sindicato, a liderança era organizada por uma comissão executiva eleita democraticamente. Na primeira eleição, foram eleitas como secretárias Elisa Gonçalves e Carmen Ribeiro, como tesoureiras Annita Cruz e Elvira Boni, e, como bibliotecária, Clara Costa. ${ }^{35}$ Logo, os seus discursos e manifestos estavam presentes nos jornais da grande imprensa, que questionavam o papel relegado à mulher na sociedade, buscavam

24 CAMPOS, B. L. "Avante, companheiras!": as lutas sindicais das operárias do Rio de Janeiro na União das Costureiras a partir da trajetória de Elvira Boni. Monografia (Graduação) - Universidade Federal de São Paulo, São Paulo, 202I. "União das Costureiras - A classe se reorganiza." Jornal do Brasil, Rio de Janeiro, II mar. I92I. O operariado, p. 8 .

26 "Um manifesto dos operários”. O Imparcial, Rio de Janeiro, 24 maio 1919. A agitação operaria, p. 3.

27 “União das Costureiras". A Razão, Rio de Janeiro, I6 jun. I919. Movimento operário: manifestos, p. 6.

28 LACERDA, E. B. "Elvira Boni: anarquismo em família”. GOMES, A. C. Velhos militantes: depoimentos. Rio de Janeiro: Zahar, 1988.

29 LACERDA, op. cit.

30 "As criadoras do luxo. Chapeleiras e costureiras". O Jornal, Maranhão, 30 jun. 1922, p. 2.

3 I LACERDA, op. cit., p. 25.

32 LACERDA, op. cit.

33 "As criadoras do luxo. Chapeleiras e costureiras". O Jornal, Maranhão, 30 jun. 1922, p. 2.

34 LACERDA, op. cit.

35 "As costureiras arregimentam-se". A Noite, Rio de Janeiro, 26 maio 1919. As reivindicações operarias, p. 4.

$6 \cdot$ ano XII, n. I7, 202I • ISSN 2179-5487 
melhorias para suas condições de trabalho, denunciavam abusos sexuais e morais, ${ }^{36}$ convocavam as mulheres operárias para a luta coletiva do proletariado e exaltavam o movimento operário nacional e internacional, especialmente o anarquista e o seu legado na luta pela jornada de oito horas. ${ }^{37} \mathrm{Na}$ assembleia de formação da União, a costureira Elisa Gonçalves dizia:

Se os homens, coligados, enérgicos e bem unidos, podem conquistar as melhorias pelas quais conscientemente se batem, por que motivo nós, as mulheres, que também trabalhamos sem tréguas, nem descanso, dez, onze e doze horas diárias, sofrendo as arrogâncias do patrões, por que nós também, companheiras, firmes e unidas não podemos vencer a nossa causa? Nós que somos tratadas de "sexo fraco", e[m] que dizem dever ter conosco um modo de tratar mais delicado e mais suave, por que razão nos impingem mais horas de trabalho sem ter quase o tempo precioso para uma ligeira refeição? O "sexo fraco", por conseguinte, sujeito a essas irregularidades, a essa escravidão, não acaba, talvez, demonstrando que é mais forte que o "sexo forte" ? 38

Após um mês de assembleias, reuniões e divulgação de manifestos em que discutiam suas longas jornadas de trabalho, as horas extras não remuneradas e os baixos salários-inclusive em relação aos homens alfaiates que estavam na mesma categoria,$-{ }^{39}$ as costureiras sindicalistas decidiram organizar um memorial para enviar aos patrões..$^{40} \mathrm{Em}$ 1920, a diferença de salário entre um homem e uma mulher adultos na indústria de confecção de roupas era de $84 \%$, enquanto os ordenados das meninas e meninos eram ainda mais baixos, quase não variando entre si. ${ }^{41}$

O memorial assinado por trezentas costureiras continha suas reivindicações gerais: jornada de oito horas de trabalho; o domingo como o dia de descanso; pagamento mensal no dia cinco; entrada no trabalho às oito horas e saída às cinco horas; uma hora de almoço; aumento dos salários de todas as trabalhadoras; aumento de $40 \%$ dos preços das peças confeccionadas em seu próprio domicílio; nenhuma demissão sem justificativa; e o reconhecimento da União das Costureiras como sindicato e

36 "O manifesto da União das Costureiras". A Razão, Rio de Janeiro, 24 maio 1919. Movimento operário à noite, p. 5 .

37 "As costureiras organizam-se. Uma grande assembleia na União dos Alfaiates. Foi criada a sua associação de classe”. A Razão, Rio de Janeiro, I9 maio 1919, p. 4.

38 Ibidem.

39 “O manifesto da União das Costureiras". A Razão, Rio de Janeiro, 24 maio 1919. Movimento operário à noite, p. 5 .

40 "As costureiras reúnem-se". O Imparcial, Rio de Janeiro, I5 jun. 1919. A agitação do operariado, p. 4.

4I FRACCARO, G. Os direitos das mulheres: feminismo e trabalho no Brasil (1917-1937). Rio de Janeiro: Editora FGV, 2018. 


\section{REVISTA ANGELUS NOVUS}

intermediário das relações de trabalho. As costureiras decidiram que, caso os patróes e patroas não aceitassem as reivindicações, elas declarariam greve; e, assim, aconteceu..$^{42}$

\section{Uma "greve de saias" ou a "greve das abelhas de luxo"}

No dia I8 de junho, costureiras de diversas oficinas e ateliês já haviam paralisado o trabalho. $\mathrm{Na}$ parte da manhã, elas se reuniram em assembleia na sede da União dos Alfaiates, onde decidiram percorrer as ruas da cidade durante o dia para conquistar mais adesões à greve. ${ }^{43}$ Os relatos e as fotografias revelam a grande quantidade de mulheres presentes na sede, inclusive mulheres negras (Imagem I), pouco presentes na historiografia do movimento operário. ${ }^{44} \mathrm{O}$ movimento das costureiras contesta veemente a visão historiográfica que opõe o trabalhador negro, "nacional", como passivo nas lutas operárias, aos estrangeiros, que seriam "ativos".45 Ao mesmo tempo, combate também o mito da passividade feminina no movimento de trabalhadores. ${ }^{46}$

Neste primeiro dia de greve, uma comissão grevista foi ao ateliê localizado no segundo andar do Café S. Paulo, onde conseguiram a adesão de duas meninas. Elas andavam de oficina em oficina e gritavam palavras de ordem: "Coragem! [...] - Nós venceremos a greve! A miséria terá um termo!”. O conflito com patrões e patroas não demoram a surgir. As costureiras denunciavam à imprensa: em uma oficina na rua do Teatro, elas foram buscar adesões, porém, o proprietário do estabelecimento as manteve em cárcere privado e ameaçou chamar a polícia para prender as "revolucionárias". ${ }^{47}$

Ainda no primeiro dia, as costureiras receberam a primeira resposta positiva às reivindicações, da casa Adolpho Marchesini. O objetivo delas era que a paralisação fosse total, e a formação de comissões para garantir mais adesões foi bem-sucedida. ${ }^{48}$ "No I $4^{\circ}$ " distrito, por exemplo, zona em que maior é o número dessas casas, tais estabelecimentos

42 “União das Costureiras”. A Razão, Rio de Janeiro, 16 jun. 1919. Movimento operário: manifestos, p. 6.

43 "Vencerão! Devem vencer...! A greve das costureiras desperta entusiasmo em todas as classes. Aspecto do movimento. Uma violência deprimente. A União das Costureiras”. A Razão, Rio de Janeiro, I8 jun. I919, p. I.

44 NASCIMENTO, A. P. “Trabalhadores negros e o 'paradigma da ausência': contribuições à História Social do Trabalho no Brasil”. Estudos Históricos, v. 29, n. 59, p. 607-626, 2016.

45 GOMES, F.; NEGRO, A. L. "As greves antes da grève: as paralisações do trabalho feitas por escravos no século XIX”. Ciência e Cultura, v. 65, p. 56-59, 2013.

46 FRACCARO, G. Os direitos das mulheres: feminismo e trabalho no Brasil (1917-1937). Rio de Janeiro: Editora FGV, 2018.

47 "Vencerão! Devem vencer...! A greve das costureiras desperta entusiasmo em todas as classes. Aspecto do movimento. Uma violência deprimente. A União das Costureiras”. A Razão, Rio de Janeiro, I8 jun. 1919, p. I.

48 "A greve das costureiras". A Razão, Rio de Janeiro, I8 jun. I919, p. 3.

$8 \cdot$ ano XII, n. 17, 2021 • ISSN 2179-5487 
estão de portas fechadas, sem trabalho.” Em muitos casos, os proprietários insultavam as costureiras e não as recebiam bem, enquanto elas mantinham uma atitude pacífica. ${ }^{4} 9$

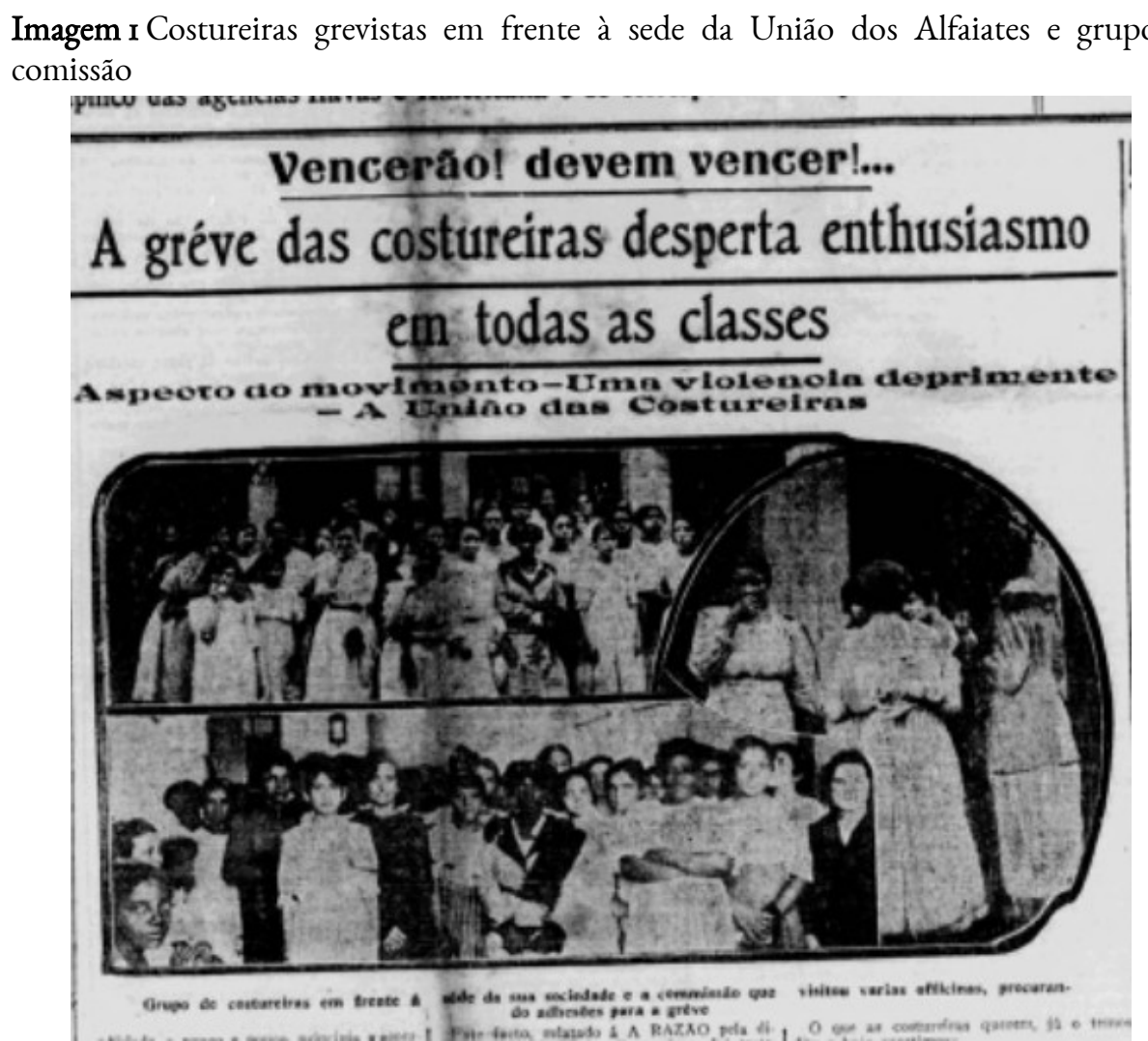

Fonte $A$ Razão, I8 jun. 1919. p. I. Hemeroteca Digital - Biblioteca Nacional.

No dia dezoito, o jornal Gazeta de Notícias realizou entrevistas sobre a greve com proprietários de estabelecimentos de moda da capital, mas não com as costureiras. De acordo com os depoimentos dos donos da Casa Colombo, Au Palais Royal, A'Voga, Casa Sucena, Águia de Ouro e Casa Sloper, a greve não as havia atingido. O senhor Melin, proprietário de A Fama e Grand Palais, afirmou que faltaram quatro costureiras ao trabalho e se mostrou disposto a dialogar, assim como o senhor Ferreira Lobo, da casa A Moda. No Mme. Judith, nenhuma trabalhadora compareceu ao serviço; e, na Casa Osório, ocorreu outro caso de cárcere privado, em que a costureira grevista, Maria, foi mantida presa em um quarto pelo proprietário do ateliê. Todos esses burgueses diziam aceitar as demandas das costureiras, com exceção do reconhecimento do sindicato..$^{\circ}$

“A greve das costureiras”. A Época, Rio de Janeiro, I8 jun. 1919. A agitação operária, p. 3.

"Uma greve de saias... As costureiras agitam-se e querem reivindicações. O dia de ontem no movimento grevista”. Gazeta de Noticias, Rio de Janeiro, I8 jun. I9I9, p. 3. 


\section{REVISTA ANGELUS NOVUS}

$\mathrm{Na}$ reunião noturna do primeiro dia de greve, muitas costureiras falaram sobre solidariedade e trocaram experiências, revelando que os dois casos de cárcere privado não foram os únicos, e que alguns proprietários recebiam as costureiras com baldes de água. Mesmo com as pressões, foi decidida a continuidade da greve: "Se os patrões não cedem, as costureiras muito menos." ${ }^{1}$

A Greve das Costureiras do Rio de Janeiro em 1919 não foi de maneira alguma isolada. Ainda que não fosse uma greve geral, ela fez parte de uma onda de greves que ocorreram em junho: ${ }^{52}$ os marmoristas, as lavadeiras, os alfaiates, os padeiros, os tecelões, os operários da construção civil e os sapateiros também fizeram paralisações. $\mathrm{O}$ jornal governista $O$ País, na seção "Casos de Polícia”, em que se noticiava o movimento operário, comparava o pacifismo dos trabalhadores grevistas em geral contra a ação direta escolhida pelos padeiros, segundo eles, "elementos maus" que bombardearam uma padaria.53 Ademais, Esse mesmo jornal negava o caráter revolucionário da União das Costureiras, afirmando que as mulheres não seguiam as ideologias dos homens comunistas e anarquistas, ${ }^{54}$ assim como enxergava o movimento dos trabalhadores não como uma luta por sobrevivência, mas como uma forma de conquistar "regalias e vantagens".ss

No segundo dia, alguns patróes e patroas recebiam as comissóes em seus estabelecimentos, enquanto outros recusavam e se mantinham hostis em relação à greve. As costureiras organizaram uma reunião às quatro horas da tarde na sede da Associação dos Gráficos, onde ocorreu uma propaganda a favor do movimento com o objetivo de conquistar mais grevistas, além de discursos de Elvira Boni e do anarquista Carlos Dias. ${ }^{6}$ As grevistas demonstravam confiança em relação à vitória da greve, e alcançaram a segunda resposta positiva em relação às suas reivindicações, da madame Lopes Passalacqua. As costureiras em greve também conquistavam apoio da opinião pública. ${ }^{57} \mathrm{Na}$ edição do dia 19, o jornal $A$ Razão destacou a exploração das crianças e das

"Uma greve de saias... As costureiras agitam-se e querem reivindicações. O dia de ontem no movimento grevista”. Gazeta de Notícias, Rio de Janeiro, I8 jun. I9I9, p. 3. 
meninas - provavelmente aprendizes -, que recebiam “minguados salários” de Io\$ooo mensais - elas também estiveram presentes na paralisação (Imagem 2)..$^{8}$

Imagem 2 Comissões de costureiras que percorreram os ateliês e buscaram adesões à greve

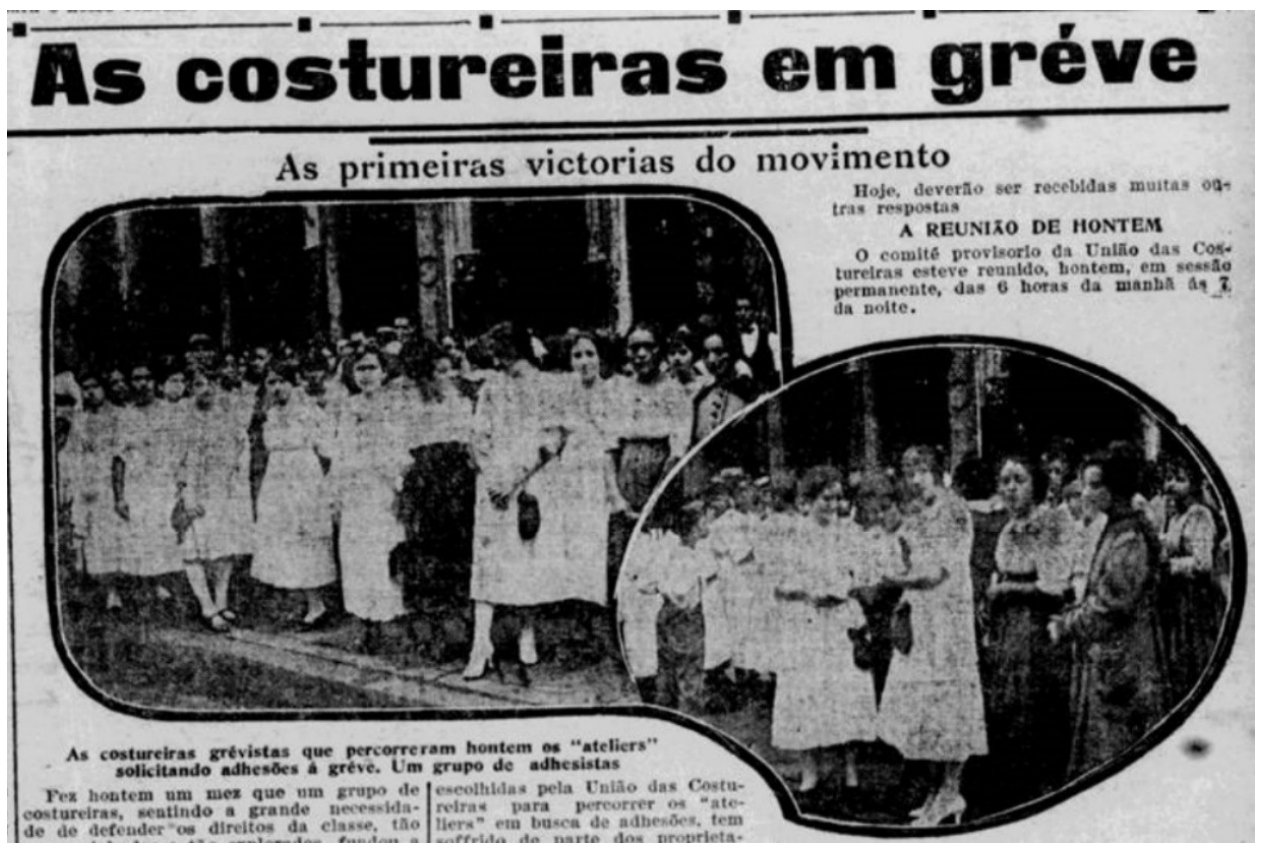

Fonte $A$ Razão, I9 jun. I919. p. I. Hemeroteca Digital - Biblioteca Nacional.

O dia 20 de junho foi chuvoso, e, por este motivo, a reunião na Associação dos Gráficos esteve esvaziada. Ainda assim, foi um dia agitado em que mais costureiras aderiram à paralisação. Os patróes, por sua vez, continuavam a impedir de todas as formas a entrada das comissões nas oficinas. $\mathrm{Na}$ rua Gomes Freire, um patrão russo ameaçou chamar a polícia para as grevistas e um outro subornou um guarda civil para maltratar as costureiras. Mais duas casas se mostraram dispostas a atender as demandas das trabalhadoras: Jayme Schwartz e Calach \& Dabdah, ambas localizadas na rua Visconde de Itaúna. No entanto, na reunião noturna, as costureiras decidiram continuar a greve até que todos os ateliês aceitassem o que foi proposto no memorial.59

No dia seguinte, na parte da manhã, as grevistas se reuniram novamente na Associação dos Gráficos, decidindo continuar a formação de grupos e comissões para percorrer as oficinas e buscar adesões. Apesar da chuva, o salão estava lotado e elas caminharam pelas ruas, no período da tarde, comprometidas com seus objetivos. $\mathrm{Na}$ assembleia vespertina, elas denunciaram as explorações dos patrões, que mantinham as costureiras presas nas oficinas para que não recebessem as grevistas, e atestaram mais

\footnotetext{
58 "As costureiras em greve. As primeiras vitórias do movimento". A Razão, Rio de Janeiro, 19 jun. I919, p. I.

59 "A greve das costureiras". A Razão, Rio de Janeiro, 20 jun. 1919, p. 4.
} 


\section{REVISTA ANGELUS NOVUS}

uma casa que aceitou o seu memorial, a Manin \& Samuel Reich. Elas protestaram contra o periódico O Jornal, e, por causa de seu menosprezo à greve das costureiras e desrespeito à classe trabalhadora, Elvira Boni sugeriu que não deixassem que seus jornalistas entrassem nas reuniōes. ${ }^{60}$

No dia 22, a greve continuava forte e com grande entusiasmo, mesmo com as permanentes ameaças dos patrões em chamar a polícia. $\mathrm{Na}$ casa Cohen, ocorreu um caso em que o proprietário, com a deflagração da greve, demitiu todas as empregadas e contratou, em seu lugar, meninas de nove a doze anos, com salários baixíssimos de 20\$ooo. Além disso, as crianças estavam recebendo maus-tratos e passando fome. Quando elas protestaram, o patrão chamou a mãe de uma delas e, ao apontá-la como grevista, ela espancou a menina e a orientou para que o empregador fizesse o mesmo se necessário. ${ }^{61}$

Ainda no dia 22, foi publicado um novo manifesto da União das Costureiras nos jornais A Razão e Gazeta de Notícias, que foram os que mais acompanharam o andamento da greve. A Gazeta de Notícias sempre utilizava a manchete "Uma greve de saias” para se referir ao movimento das costureiras, enquanto a memória de Elvira revela que o Jornal do Brasil o divulgava como a "greve das abelhas do luxo". ${ }^{62}$

No manifesto, elas recuperaram a história do sindicato e questionaram a visão de "submissão" e "inferioridade" que era atribuída às mulheres. Além disso, elas afirmaram que não convinha aos burgueses que homens e mulheres da classe trabalhadora se organizem a favor do direito à vida, e encerraram com a chamada: "Avante companheiras, à conquista do nosso bem-estar. Nada de timidez, nada de receios vãos. Para frente e com coragem." ${ }_{63}$

A greve teve continuidade, e, no dia 26 , os jornais amanheceram cheio de denúncias contra o patrão Domingues, dono de uma fábrica de camisas masculinas, pois, no dia anterior, todas as quatorze operárias de sua oficina aderiram à greve devido aos baixos salários de ıo\$ooo - o mesmo ou menor do que o de uma aprendiz. Domingues demitiu todas; procurou a União das Costureiras e, ao receber as costureiras demitidas que reivindicavam seu pagamento, as insultou e mandou prendê-las. ${ }^{64}$ Chegou a proferir um insulto racista contra a operária Laudelina Silva,

60 “As costureiras em greve. Cresce o entusiasmo da classe”. A Razão, Rio de Janeiro, 22 jun. I9I9, p. 2.

6I Ibidem.

62 LACERDA, E. B. "Elvira Boni: anarquismo em família”. GOMES, A. C. Velhos militantes: depoimentos. Rio de Janeiro: Zahar, I988.

63 "Uma greve de saias... Uma sessão agitada. O que ficou ontem resolvido". Gazeta de Notícias, Rio de Janeiro, 22 jun. 1919, p. 3 .

64 “O movimento paredista. Na fábrica do Domingues. Mais uma do delegado Severo Bonfim”. A Rua, Rio de Janeiro, 26 jun. I919, p. 2.

I2 $・$ ano XII, n. I7, 202I • ISSN 2I79-5487 
dizendo que "não queria negras vagabundas em sua casa”. Além de Laudelina, foram presas por um guarda civil as costureiras Judith Corrêa e Almerinda Machado, que protestaram junto a ela contra o racismo. ${ }^{65}$

Uma comissão de costureiras grevistas foi buscá-las na delegacia do terceiro distrito, onde também acusaram o delegado Severo Bonfim de maus-tratos e por querer colocá-las no "xadrez". Depois de muita conversa com o delegado auxiliar, Nascimento Silva, elas foram libertas. ${ }^{66}$ Portanto, no dia 26, Elvira Boni e Emma Silveira, representantes da União das Costureiras, foram junto às três operárias que que haviam sido presas e duas que haviam sido demitidas à sede do jornal $A$ Rua para publicizar suas denúncias (Imagem 3). Elvira se lembra que chegou a conversar com o chefe de polícia, Bandeira de Melo, que ele aconselhou as mulheres para não seguirem a onda dos sindicalistas da União dos Alfaiates. Mas Elvira retrucou e afirmou que elas tinham ideias próprias. ${ }^{67}$ Não era a primeira vez em que Bandeira de Melo, conhecido no Rio por participar da repressão contra movimentos grevistas, duvidava da capacidade de organização política das operárias, como o fez na Greve de 1917, em São Paulo. ${ }^{68}$

A greve continuou nos dias 27 e 28 , e as costureiras ainda aguardavam respostas dos proprietários, ${ }^{69}$ lutando para que a paralisação fosse generalizada em sua classe, chamando a atenção das operárias chapeleiras e bordadeiras. ${ }^{\circ}$ No dia 2 de julho, há indícios de que a greve ainda ocorria, quando mais uma adesão ao memorial foi conquistada, do ateliê Mme. Alzira G. Gomes, na rua Uruguayana. ${ }^{71}$ Não foi possível determinar exatamente quando a greve terminou, mas, a partir desse dia, os jornais se calaram sobre o assunto. Contudo, Elvira Boni afirma que a greve foi vitoriosa e que as costureiras conquistaram a jornada de oito horas de trabalho. ${ }^{72} \mathrm{O}$ periódico maranhense $O$ Jornal confirmou a conquista das trabalhadoras e tratou sobre a história e a dissolução da União, em 1922, realizando entrevista com Elvira e outras costureiras..$^{73}$

65 "Uma greve de saias... A polícia prende uma grevista". Gazeta de Notícias, Rio de Janeiro, 26 jun. I9I9, p. 2.

66 "O movimento paredista. Na fábrica do Domingues. Mais uma do delegado Severo Bonfim”. A Rua, Rio de Janeiro, 26 jun. 1919, p. 2.

67 LACERDA, E. B. "Elvira Boni: anarquismo em família”. GOMES, A. C. Velhos militantes: depoimentos. Rio de Janeiro: Zahar, 1988.

68 FRACCARO, G. Os direitos das mulheres: feminismo e trabalho no Brasil (19I7-I937). Rio de Janeiro: Editora FGV, 2018.

69 "Uma greve de saias... A greve continua". Gazeta de Notícias, Rio de Janeiro, 27 jun. 1919, p. 4.

70 "As costureiras agem". Correio da Manhã, Rio de Janeiro, 28 jun. 1919. O movimento grevista nesta capital, p. 3 .

7I "União das Costureiras e Classes Anexas". Gazeta de Notícias, Rio de Janeiro, 2 jul. 1919. Gazeta Operária, p. 4 .

72 LACERDA, op. cit.

73 “As criadoras do luxo. Chapeleiras e costureiras.” O Jornal, Maranhão, 30 jun. 1922, p. 2. 


\section{REVISTA ANGELUS NOVUS}

Uma provável inspiração grevista para as costureiras do Rio foi a imigrante italiana Annita Pennazzi, secretária da Liga das Costureiras de São Paulo em 1907, que também organizou uma greve em aliança com outras categorias. Annita, que era socialista e, na época da greve em que secretariou a Liga em São Paulo, tinha apenas quinze anos de idade, realizava embates com as patroas e donas de oficinas de costura da cidade. ${ }^{74}$

Imagem 3 Laudelina, Almerinda e Judith, as três costureiras que foram presas, junto a Elvira e Emma, da comissão da União das Costureiras, e duas das costureiras demitidas da fábrica do Domingues

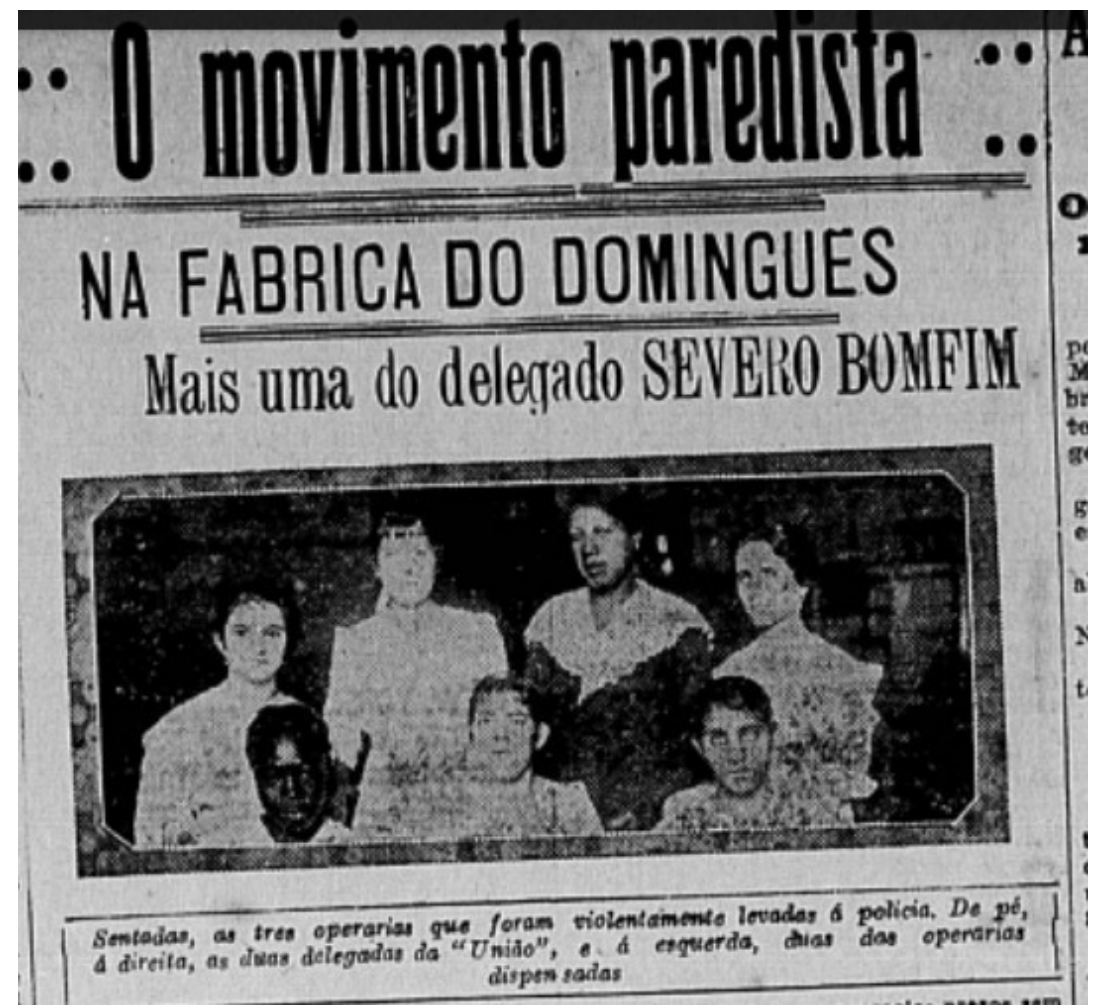

Fonte $A$ Rua, 26 jun. 1919. p. 2. Hemeroteca Digital - Biblioteca Nacional.

\section{A luta continua}

Após a greve, a União das Costureiras deu continuidade às lutas até 1922, sempre discutindo as condições de vida e trabalho das operárias em reuniões e assembleias, e estabelecendo laços de solidariedade com sindicatos da Federação dos Trabalhadores do

74 BIONDI, L. Classe e nação: trabalhadores socialistas italianos em São Paulo, 189o-1920. Campinas: Editora da Unicamp, 20II.

I4 • ano XII, n. I7, 202I • ISSN 2I79-5487 
Rio de Janeiro, como os trabalhadores marítimos, ${ }^{75}$ os alfaiates ${ }^{76}$ e os operários da construção civil. ${ }^{77}$ Alguns dos convidados das assembleias eram militantes reconhecidos do anarquismo, como Edgar Leuenroth ${ }^{78}$ e Carlos Dias, ${ }^{79}$ o anarquista negro Domingos Passos $^{80}$ e o deputado Maurício de Lacerda, ${ }^{81}$ que defendia, na Câmara, os direitos trabalhistas, inclusive para as mulheres. ${ }^{82}$ As costureiras também costumavam cantar $A$ Internacional em suas reunióes, ${ }^{83}$ uma canção importante para a união dos trabalhadores de todo o mundo. A canção rendeu boas memórias tanto para Elvira ${ }^{84}$ quanto para suas descendentes. ${ }^{85}$

Em abril de 1920, no Rio de Janeiro, ocorreu o III Congresso Operário Brasileiro, que reuniu delegados operários de todo o país e que teve participação ativa da União das Costureiras. ${ }^{86}$ Suas associadas arrecadaram $150 \$ 000$ para o evento, ${ }^{87}$ uma quantia significativa. Elvira Boni (Imagem 4) e Noêmia Lopes foram as delegadas do sindicato, as únicas mulheres presentes. ${ }^{88}$ Temas sobre a questão feminina no movimento operário foram amplamente discutidos: o trabalho noturno, a igualdade salarial e os abusos sexuais. ${ }^{89}$ Marítimos e Anexos”. Voz do Povo, Rio de Janeiro, II out. I920, p. 2.

76 “A União das Costureiras e Classes Anexas vai comemorar, amanhã, o seu primeiro aniversário”. A Noite, Rio de Janeiro, 17 maio I920, p. 2.

77 “União dos O. C. Civil. Sessão solene”. Voz do Povo, 6 abr. 1920. Vida dos trabalhadores, p. 3.

78 “Reunião das costureiras. A União das Costureiras. Hoje vai ser enviada a tabela aos patrões”. Gazeta de Notícias, Rio de Janeiro, 14 jun. I9I9.

79 “União das Costureiras e Classes Anexas.” Jornal do Brasil, Rio de Janeiro, 28 jan. I922. O operariado, p. I4.

80 "União das Costureiras e Classes Anexas." Voz do Povo, Rio de Janeiro, 6 nov. I920. Última hora: vida associativa dos trabalhadores, p. 2.

8I “União das Costureiras e Classes Anexas". Conferência pelo dr. Maurício de Lacerda. Voz do Povo, Rio de Janeiro, 27 jun. 1920, p. 2.

82 FRACCARO, G. Os direitos das mulberes: feminismo e trabalbo no Brasil (I9I7-I937). Rio de Janeiro: Editora FGV, 2018.

83 “Na União das Costureiras. A conferência de ontem do dr. Maurício de Lacerda." Voz do Povo, Rio de Janeiro, 28 jun. 1920 , p. I.

84 LACERDA, E. B. "Elvira Boni: anarquismo em família”. GOMES, A. C. Velhos militantes: depoimentos. Rio de Janeiro: Zahar, 1988.

85 CAMPOS, B. L. "Avante, companbeiras!": as lutas sindicais das operárias do Rio de Janeiro na União das Costureiras a partir da trajetória de Elvira Boni. Monografia (Graduação) - Universidade Federal de São Paulo, São Paulo, 2O2I.

86 “A instalação do 3 º Congresso Operário Brasileiro.” Voz do Povo, Rio de Janeiro, 26 abr. 1920, p. I.

87 "Federação dos Trabalhadores do Rio de Janeiro." Voz do Povo, Rio de Janeiro, 2I abr. I920. A vida dos trabalhadores, p. 3 .

88 LACERDA, op. cit.

89 "A grande realização. As resoluções do 3ํCongresso". Voz do Povo, Rio de Janeiro, Io maio ı920, p. 2. 
REVISTA ANGELUS NOVUS

Imagem 4 Elvira Boni na mesa do III Congresso Operário Brasileiro

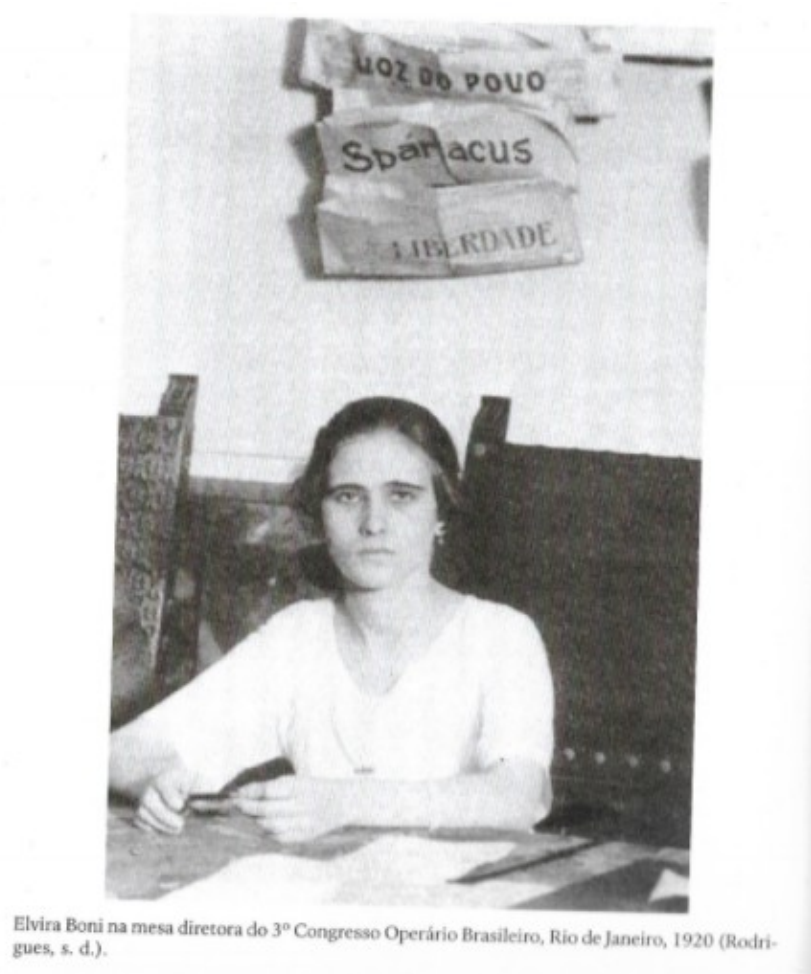

Fonte HARDMAN, F. F. Nem pátria, nem patrão!: memória operária, cultura e literatura no Brasil. São Paulo: Editora Unesp, 2002. p. 266.

Entre 1921 e 1922, as costureiras organizaram aulas noturnas de português, de aritmética e de corte e costura para mulheres, com a crença de que a alfabetização, a educação e a especialização contribuiriam para a emancipação delas. ${ }^{\circ}$ Paralelamente ao sindicato, algumas operárias participavam de outras associações. Elisa Gonçalves, Maria de Lourdes Nogueira e Emma Silveira integraram a Liga Comunista Feminina - vinculada ao primeiro Partido Comunista do Brasil, fundado em 1919 -,${ }^{91} \mathrm{O}$ Centro Feminino de Estudos Sociais ${ }^{22}$ e o Grupo Feminino Instrutivo e Recreativo Operário. ${ }^{93}$ Elvira Boni fundou a Liga Feminista Brasileira, ${ }^{94}$ assim como participava ativamente, como atriz, desde os doze anos, junto aos seus irmãos e irmãs, do Grupo de Teatro Primeiro de Maio, vinculado à Liga Anticlerical.95

90 "A União das Costureiras a educação da classe operária feminina”. Jornal do Brasil, Rio de Janeiro, I4 jul. I92I. Pela instrução, p. 9; "Pela instrução da classe operária feminina. Ao público em geral". A Razão, Rio de Janeiro, 21 jul. ı22r. Pelo mundo operário, p. 6.

91 “Liga Comunista Feminina”. Spartacus, Rio de Janeiro, 9 ago. 1919, p. 2.

92 "Grupo Feminino de Estudos Sociais. Um manifesto à mulher brasileira". Voz do Povo, Rio de Janeiro, 7 fev. 1920, p. I.

93 "Uma bela iniciativa”. Voz do Povo, Rio de Janeiro, 7 mar. 1920, p. 2.

94 "Liga Feminista Brasileira”. A Razão, Rio de Janeiro, 22 maio I919, p. 6.

$16 \bullet$ ano XII, n. 17, 202I • ISSN 2179-5487 
É interessante pensar também nas formas de sociabilidade das mulheres operárias, que, em muitos casos, estavam ligadas à vizinhança e às relações familiares. ${ }^{96}$ É possível especular que Annita Villanova e Quinta Villanova, em razão do sobrenome, poderiam ser irmãs ou parentes, e que a proximidade das costureiras com Carlos Villanova, do Sindicato dos Trabalhadores Marítimos, ${ }^{97}$ era tanta que ele também poderia fazer parte da mesma família. A história oral pode reforçar essa tese: Elvira se lembra de ir com duas irmãs da União das Costureiras visitar um irmão preso, que era ativo no movimento operário. ${ }^{9}$

Mesmo fora do contexto de greve, os abusos dos patrões e patroas eram cotidianos, e, muitas vezes, foram denunciados pelo jornal operário Voz do Povo, fundado em 1920. É possível citar o caso dos insultos da contramestra da Casa Colombo, Angelina Fontes, a uma operária, ${ }^{99}$ e a própria Elvira Boni que foi forçada a trabalhar incansavelmente fora do horário comercial por um casal proprietário da Moda Elegante. ${ }^{100}$ A trabalhadora e membro da comissão executiva da União das Costureiras, Catharina Dutra Abrantes, ${ }^{\text {Ior }}$ foi acusada injustamente de roubo na oficina de Samuel Reich \& Irmão, ${ }^{102}$ revelando a perseguição política contra essas mulheres. ${ }^{103}$

No fim de 1920, a repressão do Estado contra a onda de greves e revoltas dos trabalhadores urbanos de 1917 a 1919 atingiu a Voz do Povo, órgão principal da Federação dos Trabalhadores do Rio de Janeiro - o jornal foi empastelado, ou “estrangulado". ${ }^{104}$ A repressão sistemática atingiu grande parte dos sindicatos de resistência, inclusive a União das Costureiras, que fechou em 1922. ${ }^{105} \mathrm{O}$ jornal $O$ Brasil, de forma sexista, associava a dissolução do sindicato à incompatibilidade "natural” e à

95 LACERDA, E. B. "Elvira Boni: anarquismo em família”. GOMES, A. C. Velhos militantes: depoimentos. Rio de Janeiro: Zahar, 1988.

96 FRACCARO, G. Os direitos das mulheres: feminismo e trabalho no Brasil (1917-1937). Rio de Janeiro: Editora FGV, 2018.

97 “A sessão inaugural do Sindicato dos Taifeiros, Culinários e Panificadores Marítimos". Voz do Povo, Rio de Janeiro, 26 nov. I920, p. 2.

98 LACERDA, op. cit.

99 "O povo reclama”. Voz do Povo, Rio de Janeiro, 26 abr. 1920. Vida dos trabalhadores, p. 3.

Ioo “Na 'moda elegante'. A camarada Elvira Boni vítima da prepotência e da estupidez dum espertalhão”. Voz do Povo, Rio de Janeiro, I2 jun. 1920, p. 2.

IOI "União das Costureiras e Artes Anexas. Assembleia realizada". Voz do Povo, Rio de Janeiro, 4 set. 1920. Vida associativa dos trabalhadores, p. 3 .

IO2 "União das Costureiras e Classes Anexas". Voz do Povo, Rio de Janeiro, I2 out. 1920. Vida associativa dos trabalhadores, p. 3 .

IO3 FRACCARO, op. cit.

IO4 SODRÉ, N. W. História da imprensa no Brasil. 2. ed. Rio de Janeiro: Graal, 1977.

Io5 "Foi dissolvida a União das Costureiras". Jornal do Brasil, Rio de Janeiro, 23 maio I922, p. I3. 


\section{REVISTA ANGELUS NOVUS}

"timidez das mocinhas", ${ }^{106}$ que, na realidade, era um padrão de comportamento imposto pela opressão de gênero. ${ }^{107}$

Elvira Boni, por sua vez, lamentava a falta de organização entre as mulheres ${ }^{108}$ e a falta de identidade operária em algumas companheiras de trabalho: "Achavam que não eram operárias, e sim artistas, porque faziam coisas bonitas, vestidos [...] operário trabalhava com máquina. [...] E sindicato era coisa de operário. [...] E é.”og

A dificuldade de participação em reuniões noturnas estava ligada às duplas ou triplas jornadas de trabalho, que envolvia as ocupações relegadas ao gênero feminino: a maternidade, as tarefas domésticas e o trabalho de cuidados. ${ }^{\text {Iо }}$ No período do comunismo de guerra na União Soviética, além das conquistas de direitos das mulheres na Constituição de 19I8, o trabalho feminino estava sendo socializado com a criação de lavanderias e cozinhas coletivas, assim como creches. É possível associar as ideias de emancipação feminina das costureiras brasileiras com as das bolcheviques Alexandra Kollontai e Nadiedja Krupskaia, contemporâneas que visavam o rompimento com a ordem burguesa e a exploração capitalista, e insistiam na união da classe trabalhadora. ${ }^{\text {II }}$

Apesar do fechamento do sindicato e da eventual perda dos direitos conquistados pela Greve de 1919 - que não eram garantidos na Constituição e que dependiam das próprias negociações entre patrões e trabalhadoras -, é possível afirmar que a luta e resistência das mulheres operárias durante a Primeira República foi essencial para a conquista de direitos trabalhistas durante a Era Vargas. ${ }^{\text {2 }}$ Seus direitos não foram dados, mas arrancados por elas. Para Elvira Boni, “[...] se não fôssemos nós, Getúlio Vargas não teria assinado as leis trabalhistas que assinou, e que, mesmo assim, continuam até hoje a ser burladas. Realmente, digo que o sacrifício foi muito grande, mas acho que começaria tudo de novo se fosse possível. [...] faria tudo de novo.” ${ }_{\text {II }}$

\footnotetext{
Io6 "Ecos operários". O Brasil, Rio de Janeiro, I8 abr. 1922. Vida proletária, p. 5.

I07 RAGO, M. Do cabaré ao lar: a utopia da cidade disciplinar: Brasil (I890-1930). Rio de Janeiro: Paz e Terra, 1985 .

IO8 “As criadoras do luxo. Chapeleiras e costureiras". O Jornal, Maranhão, 30 jun. 1922, p. 2.

Io9 LACERDA, E. B. "Elvira Boni: anarquismo em família". GOMES, A. C. Velhos militantes: depoimentos. Rio de Janeiro: Zahar, 1988, p. 37.

IIo FRACCARO, G. Os direitos das mulheres: feminismo e trabalho no Brasil (I9I7-I937). Rio de Janeiro: Editora FGV, 2018.

III SCHNEIDER, G. (Org.) A revolução das mulheres: emancipação feminina na Rússia soviética. São Paulo: Boitempo, 2017.

II2 FRACCARO, op. cit.

II3 LACERDA, E. B. "Elvira Boni: anarquismo em família”. GOMES, A. C. Velhos militantes: depoimentos. Rio de Janeiro: Zahar, 1988, p. 67.
}

I8 $・$ ano XII, n. I7, 202I • ISSN 2179-5487 


\section{Considerações finais}

Apesar das dificuldades diante da vida das mulheres proletárias do Rio de Janeiro no início do século $\mathrm{XX}$, as costureiras conseguiram se organizar em um sindicato de resistência e conquistar direitos através de uma greve vitoriosa. Através de reuniões, assembleias e congressos, expunham suas ideias e inquietações, seus projetos de uma sociedade futura, e suas preocupações imediatas, organizando diversas táticas de luta.

Nos últimos anos, o avanço do neoliberalismo promoveu uma violenta retirada de direitos trabalhistas através da Reforma Trabalhista, Reforma da Previdência, PEC do Teto de Gastos, Carteira Verde e Amarela, entre outros ataques as classes trabalhadoras brasileiras. É importante que os historiadores recuperarem a história dos trabalhadores e das trabalhadoras que lutaram para conquistar direitos econômicos e políticos, e que podem inspirar e estimular as lutas atuais, expressiva entre as lutas dos entregadores de aplicativos, cuja semelhança com a situação do liberalismo da Primeira República é evidente. Ressalto que a luta de classes no contexto brasileiro se apresenta de diversas formas na atualidade, e que o golpe contra Dilma Rousseff, apoiado pela burguesia, ocorreu logo após uma grande conquista derivada de décadas de luta das mulheres trabalhadoras: a PEC das Domésticas.

À margem do feminismo hegemônico, que atribui a "primeira onda” às sufragistas no início do século XX, as mulheres de chão de fábrica e de oficinas de costura estavam construindo uma noção própria de igualdade entre homens e mulheres, bem como de emancipação operária e feminina, ${ }^{\mathrm{II}}$ que, em muitos casos, visava a superação do capitalismo e a construção de uma nova ordem social: a anarquista, por meio da autogestão dos trabalhadores e a ausência do Estado; a sindicalista revolucionária, com os sindicatos como embriões da nova sociedade; ou a comunista, com a tomada do Estado e a construção do socialismo pela classe trabalhadora. ${ }^{\text {I }}$

II4 FRACCARO, G. Os direitos das mulberes: feminismo e trabalho no Brasil (1917-1937). Rio de Janeiro: Editora FGV, 2018.

IIs TOLEDO, E. Anarquismo e sindicalismo revolucionário: trabalhadores e militantes na Primeira República. São Paulo: Fundação Perseu Abramo, 2004. 